DOI: 10.17117/na.2016.07.02.307

Поступила (Received): 26.07.2016

\title{
Кишкинова E.M.
}

Ростовский архитектор Александр Позняков: штрихи к неоконченному портрету

\author{
Kishkinova E.M. \\ Rostov architect Alexander Poznyakov: finishing \\ touches to the unfinished portrait
}

Статья посвящена малоисследованному творчеству одного из ведущих архитекторов Ростова-на-Дону начала ХХ века - А.В. Познякова. Выявляются и анализируются его постройки общественные и производственные здания, доходный дом, уточняется их стилевая принадлежность. Характерные для творческого почерка архитектора приемы рассматриваются в контексте модерна и неоклассицизма

Ключевые слова: архитектура Ростова-на-Дону начала ХХ века

\section{Кишкинова Евгения Михайловна}

Кандидат искусствоведения, доцент, зав. кафедрой Академия строительства и архитектуры Донского государственного технического университета

2. Ростов-на-Дону, ул. Социалистическая, 162

\begin{abstract}
The article is devoted little explored creative work of one of the leading architects of Rostov-on-Don the beginning of the XX century - A.V. Poznyakova. Identify and analyze its construction - public and industrial buildings, apartment house, clarifies their stylistic identity. Specific to the creative style of the architect techniques considered in the context of Art Nouveau and neoclassical
\end{abstract}

Key words: architecture of Rostov-on-Don the beginning of XX century

\author{
Kishkinova Evgeniya Mkihailovna \\ Candidate of Art Criticism, Associate Professor, Hed \\ of Department \\ Academy of construction and architecture of the Don \\ state technical university \\ Rostov-on-Don, Sotsialisticheskaya st., 162
}

Рубеж XIX и XX столетий был отмечен в Ростове большой строительной активностью. Именно в этот период центральная часть города приобрела особенно респектабельный вид, соответствующий значению крупного торговопромышленного центра Юга России. В Ростове возводились здания по проектам известных зодчих, академиков архитектуры А.Н. Померанцева, М.М. Перетятковича, А.Н. Бекетова. Но основной вклад в застройку внесли, естественно, жившие в Ростове архитекторы, среди которых известны имена Г.Н. Васильева, Е.М. Гулина, Н.А. Дорошенко, Н.Н. Дурбаха, П.Я. Любимова, Н.М. Соколова, Л.Л. Эберга и многих других. И все же «белые пятин» немало. В войнах и социальных потрясениях разрушились здания, стерлась память об их авторах, утратились документы, которые могли бы пролить счет на их судьбу. Среди незаслуженно забытых зодчих есть и те, чьи постройки по сей день являются достойной и неотъемлемой частью облика города. Олин из них - Александр Владимирович Позняков. 
Он родился в Ростове в 1882 году, здесь же, в реальном училище, получил среднее образование, а высшее - в петербургском Институте гражданских инженеров, которой окончил в 1907 году. После этого два года Позняков работал в Московской и Вологодской губерниях, построил несколько школьных зданий, женскую гимназию в г. Тотьме, гостиницу Варварова в г. Ейске.

В 1909 году архитектор вернулся в родной город и занялся самостоятельной практикой [1, стр. не обозн.]. Справочник «Весь Ростов и Нахичевань-наДону» сообщает адрес архитектора и гражданского инженера А.В. Познякова 7-я линия, дом №17 [2, столб. 153]. К сожалению, не сохранились возведенные им в Нахичевани особняки И.Е. Чернышенко, В.С. Зипалова, В. Пановой, названные в юбилейном издании «Россия в ее прошлом и настоящем», где из многих работавших в Ростове зодчих отмечены лишь двое - Л.Л. Эберг и А.В. Позняков. Обоим им было в то время по 33 года, но современники уже успели по достоинству оценить их творчество.

Эту высокую оценку подтверждают и фамилии заказчиков Познякова: согласно той же «России в ее прошлом и настоящем», он возвел в Ростове гостиницу Кундури, доходные дома Кошкина, Кулакова, Келле-Шагинова, Емалаки. Евстафий Георгиевич Кундури - член Роствоского биржевого общества, председатель комитета торговли и мануфактур, португальский вице-консул, зять табачного фабриканта Я.С. Кушнарева, член всех ростовских благотворительных обществ; Матвей Осипович Кулаков - крупный купец, занимавшийся винно-бакалейной торговлей; И.М. Келле-Шагинов и И.С. Кошкин - также представители торговопромышленной элиты города. Построены А.В. Позняковым в период с 1909 по 1915 годы «в Донской области церковь и архиерейское подворье, в Ростове-наДону Коммерческий клуб», в Нахичевани - завод сельскохозяйственных машин «Аксай», «общее число проектов - около 40, из них осуществлено 35», специализировался он на «постройках церквей, доходных домов и общественных зданий...в русском, классическом и нормандском стилях» [1, стр. не обозн].

Из этих многочисленных работ на сегодняшний день выявлены лишь некоторые. Наиболее значительные - возведенная в 1914 г. гостиница Кундури (Буденовский, 43, ныне штаб СКВО), и Коммерческий клуб, построенный в 19121915 гг. (Буденовский, 34, ныне Дом офицеров). Ростовские краеведы традиционно приписывают оба эти памятника совместному творчеству А.В.Познякова и Арутюна Христофоровича Закиева (1874-1945), однако в указанном издании их автором назван Позняков. Доля участия каждого из зодчих в их проектировании и строительстве требует дополнительного исследования.

Здание бывшего Коммерческого клуба протяженным несимметричным фасадом также выходит на нынешний Буденовский проспект. Верхний этаж трактован как аттиковый, нижний - как цокольный. Левая половина четырехэтажного здания, включающая парадный вход, завершена треугольным выступом и фланкирована слабо раскрепованными ризалитами, включающими в уровне четвертого этажа термальные окна, в архивольты которых вкомпонованы розетки, а в подоконные ниши - рельефные кольца с женскими масками, дополненные пальметтами, тройные узкие окна в уровне третьего этажа и арочные окна с замковыми камнями - в уровне второго. Аналогичный ризалит 
замыкает правую половину фасада. Центральная часть левого крыла выделяется наличием рельефных скульптурных групп в межоконных простенках верхнего этажа. Здесь представлены фигуры в античных одеждах, с кадуцеями и лирами в руках, что соответствует изначальному назначению здания. Над окнами третьего этажа помещены филенки, заполненные меандром по горизонтальным краям, розеткой в центре и волнообразно изогнутыми «каннелюрами» слева и справа от нее, а над окнами второго - широкий фриз с вазами и лавровыми гирляндами. Правое крыло монументализиорвано колоннадой из гигантских полуколонн ионического ордера, объединяющего второй и третий этажи. По воспоминаниям Закиева, первый этаж включал общий вестибюль и вестибюль для членов клуба, библиотека и читальный зал. В правой части находились магазины. На втором этаже размещались «фойе, концертно-танцевальный зал, дамская гостиная, мужская комната отдыха, курительная компания, помещение правления, игорный зал, малый буфет, гримуборная и ряд вспомогательных помещений. На 3-м этаже большая столовая, малая клубная, биллиардный зал, помещения административно-служебного характера и вспомогательные помещения, большой зал с хорами. Что касается оформления интерьеров, то вестибюль был обработан в дорическом ордере с высокими панелями и колоннами из искусственного мрамора. Столовая отделана светлым дубом. Стены зала на 3-м этаже на высоту декоров облицованы мрамором. Карнизы и потолок украшены лепниной» [3].

В бывшем здании гостиницы «Палас-отель» с 1918 г. размещается штаб Северо-Кавказского военного округа. В ходе надстройки, осуществленной в 1930 х годах, облик здания претерпел существенные изменения. Выдержанная в неоклассицизме постройка изначально была трехэтажной и завершалась парапетом над венчающим карнизом. Срезанную угловую часть акцентировал пологий купол. Его цилиндрический барабан покоился на граненом основании, прорезанном овальными окнами, которое, в свою очередь, возвышалось над аттиком, украшенном гирляндами и дополненном четырьмя монументальными скульптурными фигурами. Пропорции и декор этой части здания при перестройке были существенно изменены, хотя мотив купола сохранился. В угловой части на первом этаже размещены вестибюль и парадная лестница. Г-образный план включает поэтажно расположенные широкие коридоры, по обеим сторонам которых находились обширные номера гостиницы, оборудованные, по свидетельствам рекламы того времени, горячей и холодной водой и телефонами. Гостиница была рассчитана на 70 номеров и имела собственный ресторан. Нижний рустованный этаж здания трактован как цокольный. Протяженным фасадам соответствуют укрупненные детали. Вертикальными членениями служат узкие раскреповки, трехгранные эркеры, связывающие основные этажи и фланкирующие фасады, а также гигантского ордера ионические и коринфские пилястры. Вход с угла акцентирован двумя колоннами, поддерживающими балкон. Несмотря на искажения первоначального облика, здание и сегодня производит сильное впечатление благодаря согласованности монументальных пропорций, удачной акцентировке углового положения при помощи купола, размеренному ритму крупных членений, пластическому разнообразию фасадов и, 
наконец, красиво прорисованным сочным лепным деталям, контрастно сопоставленным с гладкими поверхностями.

Использование укрупненных вертикальных членений, объединяющих этажи, стремление разнообразить плоскость фасада введением эркеров, увлечение классицистическими элементами и внимание к немногим лепным украшениям отличают и другую постройку Познякова - доходный дом Кулакова (Б.Садовая, 164), возведенную в 1910 году в стиле модерн. Здание Г-образное в плане, фасад почти симметричен. Лестничная клетка имеет только верхнее освещение; планировка этажей секционная. Частично сохранились строгие классицистические интерьеры вестибюля и парадной лестницы. Вертикализм узкого четырехэтажного фасада многократно подчеркнут незначительными раскреповками и пятью эркерами, включающими тройки узких окон. Отграниченные гигантскими ионическими пилястрами боковые эркеры, дугообразные в плане, охватывают третий и четвертый этажи, расчленяются лопатками и завершаются фризами с грифонами, картушами и лавровыми гирляндами. Главным же их украшением служат замкнутые в шестиугольники рельефные фигуры в струящихся одеждах. Центральные трехгранные эркеры объединят второй, третий и четвертый этажи. Выступают они слабее, их дополняют каннелированные лопатки, а венчают фронтоны. Разнообразие эркеров придает фасаду «вибрирующий» характер. Фасад дополняют прямоугольные филенки и балконы с решетками строгого рисунка. Приподнятая упругими волнистыми ступенями центральная часть в верхней точке завершается печальным женским ликом, слева и справа им вторят гирлянды; ниже помещено овальное окно, его фланкируют вертикали лавровой вязки. Первый этаж занят обширными витринами магазинов. В целом при значительной высоте здания фасад его отличается особой камерностью, нежностью приглушенного звучания, в котором как бы повторяется и варьируется мелодия взлетающих и ниспадающих линий, и той сдержанностью, которую приобретает модерн, не чуждый влияния неоклассицизма.

Еще одна работа Познякова - доходный дом И.М.Келле-Шагинова (ул. Станиславского, 100/89) - не имеет точной датировки. Учитывая, что в данном случае автор использовал в оформлении фасадов приемы модерна, а не неоклассицизма, можно предположить, что эта постройка относится к началу 1910-х годов. Запоминающийся силуэт симметричному фасаду четырехэтажного здания придают трапециевидные выступы, завершающие три незначительно раскрепованных ризалита и включающие небольшие окна. Под венчающим карнизом, поддерживаемым металлическими кронштейнами, помещена легкая рельефная гирлянда с венками. Простенки боковых ризалитов в уровне третьего этажа оживляют рельефные картуши с гирляндами. Плоскость стен разнообразят трехгранные эркеры: центральный, охватывающий второй-четвертый этажи, и боковые, объединяющие третий и четвертый. Окна первого и третьего этажей имеют дугообразные завершения, а окна второго и четвертого - трапециевидные, характерные для модерна. При этом проемы второго этажа объединены по горизонтали широкой лентой рельефного шашечного орнамента, а проемы четвертого - также рельефной полосой с выступами и западами, подоконные ниши оформлены квадратными ступенчатыми филенками. Штукатурка «под шубу» в 
ленточном русте первого этажа и архивольте центрального входа, поддерживаемом приземистыми колоннами, сообщают фасаду родство с северным модерном.

Умение организовать большие массы, придать им определенный ритм и извлечь эстетический смысл из самых простых форм характеризуют возведенный Позняковым одновременно с гостиницей Кундури, в 1914 году, новый корпус завода «Аксай» (35-я линия, 83). Медно-чугунолитейный завод «Аксай» был основан в 1891 году торгово-промышленным товариществом «В.М.Григорьев и К요, а в 1900 г. перешел в ведение акционерного общества «Аксай». В начале XX века он выпускал плуги, жатки, автомобили, лодочные моторы, тракторы, комбайны. Яркая история завода, его расцвет в советское время и банкротство в 2011 году - за пределами рамок настоящей статьи, отметим лишь, что ныне все корпуса предприятия, включая построенные Позняковым, находятся в руинированном состоянии.

Фасад здания цехов прорезан двумя широкими полосами мелкоостекленных ленточных окон со срезанными верхними углами. Вертикальные членения представлены лопатками. Заводоуправление декорировано намного насыщеннее и составляет контраст с заводскими корпусами, в то же время гармонируя с ними. Это здание трехэтажное, нижний цокольный этаж рустован, два верхних традиционно для Познякова объединены пилястрами. Иллюзию раскреповки создают пучки лопаток, выделяющих центральную и боковые части фасада. Они завершаются ступенчатыми аттиками с дугообразными окнами. Горизонтали представлены междуэтажными тягами и развитым карнизом на крупных сухариках. Центр акцентирован термальным окном, помещенным над главным входом. Строгое и простое, но достаточно выразительное, в соответствии со своим назначением, здание это дает возможность почувствовать руку опытного мастера, способного решать весьма разнообразные задачи, в том числе в области промышленной архитектуры.

Как сложилась судьба А.В.Познякова после революции - не известно; биография его требует дальнейшего исследования, а работы - выявления и идентификации. Но даже то немногое, что сегодня с уверенностью можно отнести к постройкам Александра Владимировича Познякова, позволяет говорить о нем как о крупном и талантливом зодчем-профессионале, обладавшем творческой самобытностью.

\section{Список используемых источников:}

1. Россия в ее прошлом и настоящем. В память 300-летия царствования Державного Дома Романовых. М., 1915. 1240 с.

2. Весь Ростов и Нахичевань-на-Дону за 1914 год. Харьков, 1914. 189 с.

3. Петухова Н.Я. Арутюн Христофорович Закиев - архитектор Нахичевани. URL: http://www.nahichevan.ru/zakiev.htm

(C) 2016, Кишкинова Е.M.

Ростовский архитектор Александр Позняков:

итрихи к неоконченному портрету
(C) 2016, Kishkinova E.M. Rostov architect Alexander Poznyakov: finishing touches to the unfinished portrait 